\title{
AGON AND THE SIGNIFICANCE OF VICTORY AT THE CEREMONIAL GAMES IN OLYMPIA
}

\author{
Vojkan Selakovići ${ }^{1}$ Violeta Šiljak $^{1}$ and Milan Brkin ${ }^{2}$ \\ ${ }^{1}$ FIEP Europe, Section for physical education and sport \\ ${ }^{2}$ European Center for Peace and Development of UN Universities for Peace, Belgrade, Serbia
}

UDK 796.032.2(495)

\begin{abstract}
SUMMARY
The ideology of one of the most important global sporting events of today, the modern Olympic Games, focused on participation rather than victory, promoting equality among participants rather than domination of the victors over the defeated, established ideal models of sportsmanship and sports ethics of today based on the values of ancient society. The subject of this paper refers to the agon and the significance of winning the Ceremonial Games in Olympia. The objective of the paper is to determine the significance of the victory at the Ceremonial Games in Olympia through a review of primary and secondary historical sources, as well as to point out the connection between the victory and the agon. The historical method and the method of theoretical analysis are both applied in the paper. The results of the research point to the fact that the Ceremonial Games in Olympia were shaped by the general Greek phenomenon of expressed competitiveness or agon, the concept of honourable rivalry in all spheres of social life, with the purpose of proving excellence and superiority over competitors, and which as such became the main driving force of the development of ancient Greek culture, on the foundations of which the entire Western civilization rests today.
\end{abstract}

Keywords: urge to compete, ancient Greece, Olympic Games, victory

Corresponding author

Violeta Šiljak

vikica.siljak@gmail.com

\section{INTRODUCTION}

The Olympic Games, in their international form as we know it today, were first held in 1896 in Athens. The establishment of the Games was the culmination of 
many years of efforts by the French historian and pedagogue, Baron Pierre de Coubertin, and many rarely mentioned associates of his, to "revive" the athletic tradition and ideology of the Ceremonial Games in ancient Olympia, which he saw as the embodiment of sports culture and sports competition. De Coubertin's interpretation of the ancient Olympic Games was the ideological basis of the modern Olympic Games and their institutions, such as Olympism, which Coubertin himself summed up in a message in 1932, sending it on the occasion of the tenth modern Games held in Los Angeles, which read "The most important thing in the Olympic Games is not winning but taking part" 1 . It is this philosophy, known today as the Olympic creed, that has largely shaped the modern experience of the ethics of both professional and amateur sports, by promoting the ancient heritage. Still, such a philosophy of competition is almost in complete contradiction with the uncompromising principles on which the ancient Greek Games were based, and the general understanding of competition by the ancient Greeks. The ancient Games were unquestionably ruled by agon, the urge to compete, while the contrast between the winners and the defeated was pronounced to such an extent that absolute triumph, the only socially acceptable outcome of the competition, was elevated to the level of the mythical. In contrast, in defeat there was no room for pity or justification, only boundless sorrow and shame of the defeated ${ }^{2}$. The foundations of the ancient athletic competition were sung in the first known part of ancient Greek literature - the epic poem Iliad, in the form of the motto: "Always be the first and superior to the others" 3 .

\section{SUBJECT, OBJECTIVE AND METHOD OF WORK}

The subject of this paper refers to the agon and the significance of winning the Ceremonial Games in Olympia. The objective of the paper is to determine the significance of the victory at the Ceremonial Games in Olympia through a review of primary and secondary historical sources, as well as to point out the connection between the victory and the agon. The historical method and the method of theoretical analysis are both applied in the paper.

\footnotetext{
${ }^{1}$ David Young, „On the Source of the Olympic Credo“, OLYMPIKA The International Journal of Olympic Studies, Vol. III, 1994, p 17.

2 Pindar, Odes and Fragments. Pythian VIII, (translated from Greek by T. Smerdel), Matica Hrvatska, Zagreb, 1952, pp 154-158.

${ }^{3}$ Homer, Iliad, (translated by. M. N. Đurić), Matica Srpska, Subotica, 1977, p 288.
} 


\section{RESULTS AND DISCUSSION}

\section{Agon}

Etymologically, the word agon ( $\alpha \gamma \omega \dot{v}$ ) first appears in Homer and means meeting or gathering 4 , especially in the context of gathering to watch athletic competitions ${ }^{5}$. Agon was also used to denote the location where the competition took place ${ }^{6}$, but signified the athletic competition itself, whether in Olympia, Nemea, Delphi or Isthmus ${ }^{7}$, as well as any other competition for the prize ${ }^{8}$, be it athletic, equestrian, musical, and regardless of whether the prize was a wreath ${ }^{9}$ or some other material reward ${ }^{10}$. Agon, in addition, carried the meaning of a fight, battle, or an activity that requires extreme effort, such as those of Hercules, superhuman feats or even armed conflicts. The context of these meanings of the term agon, reveals the true nature of athletic competitions, which for a reason represent terminological equivalence of violent conflicts and military campaigns, from which they arose ${ }^{11}$.

As an urge to compete, prove oneself, or establish supremacy over rivals, agon became a fundamental factor in the formation of ancient Greek culture, responsible for every feat, whether in the realm of athletic, cultural, artistic, or political achievements, through which Greeks became aware of their spiritual unity despite mutual differences ${ }^{12}$. The origin of this phenomenon of competitiveness was defined by the writer Hesiod in his work "Works and Days", as early as the 7th century $\mathrm{BC}$, through the story of two Erides, two divine antagonists, the personification of "inherent discord among people"13. The older (inherent), which awakens healthy competition, leads people towards improvement and progress, and the younger (acquired), which represents the dark side of competitiveness, warns of the dangers that unbridled ambition brings

\footnotetext{
${ }^{4}$ Ibid., p 258.

${ }^{5}$ Ibid., pp 192 and 450.

${ }^{6}$ Ibid., p 685.

${ }^{7}$ Herodotus, and A. D. Godley. Herodotus. Vol. 3, Cambridge, MA: Harvard University Press, 1969, p 283.

${ }^{8}$ Ibid., Vol.1, p 375.

${ }^{9}$ Ibid.,Vol. 3, p 125; A. R. Shilleto, trans. Description of Greece, Pausanias. Vol 1., London, George Bell, 1886. p 314

${ }^{10}$ Pindar, Odes and Fragments. Nemean $X$, (translated from Greek by T. Smerdel), Matica Hrvatska, Zagreb, 1952 p 223-228.

${ }^{11}$ Violeta Šiljak, Slađana Mijatović and Ivana Parčina, Politics and the Olympics, Topics (Teme), vol. 37, no. 2, 2013, p 889; Đorđe Stefanović, Theory and practice of sports training, Faculty of Sports and Physical Education, Belgrade, 2006, p 11.

${ }^{12}$ Violeta Šiljak, History of Sports, Faculty of Sports Management, Belgrade, 2007, p 42.

${ }^{13}$ Hesiod, Works and Days. The origin of the gods. Homer's Hymns, (translated by Branimir Glavičić), Demetra Philological Library of Dimitrije Savić, Vol 6, Zagreb, 2005, pp 11-24.
} 
with it. The emergence of these two capital works of Greek literature, which testify to the competitive spirit of the Greeks, coexists with the spread of the phenomenon of agonal competition among a narrow circle of aristocracy, which marked the post-Mycenaean, the so-called dark ages, somewhat the Homer's time as well (around 1100-800 BC), to other social strata during the archaic era. Thus, there are fantastic examples of competition among slaves ${ }^{14}$, women ${ }^{15}$, children ${ }^{16}$, warriors ${ }^{17}$, and even entire polises ${ }^{18}$. Agonism, as an almost institutionalized phenomenon, took its full form in Greek society during the peak of the archaic age, with the formalization of athletic festivals and the development of the polis, when sports competitions became a fundamental expression of Greek agonism. These are born out of the need to ensure survival and establish supremacy over rival forces, out of a desire for communication among divided tribes ${ }^{19}$, but also for social recognition. The basic means of competition is effort, which mobilizes all physical and mental powers to achieve the best possible result in a given competition, and it is defined by the Greek term atla, with the meaning of competition or effort, a feat for which an award is received - the root of today's words athletes and athletics. Although it is believed that almost every inhabited place in Greece had its local athletic competition, during the archaic era, the four largest Panhellenic festivals stood out: Delphi, Isthmus, Nemea and the oldest and most important, Olympia.

\section{Agon in Olympia}

When during the archaeological excavations at the site of Olympia, the marble base of a victorious statue was found, few could have expected that one of the most picturesque and concrete explanations of the ideology and motives of the entire process of preparation and passionate competition in Olympia would be found thereon. The following text was inscribed in the marble: "Euthymus of Locri, son of Astycles, having won three times at Olympia, erected this statue to be admired by mortals. Euthymus of Locri Epizephyrii consecrated it. Pythagoras of Samos made

\footnotetext{
${ }^{14}$ Homer Odyssey, (translated by: M. N. Đurić), Matica Srpska, Subotica, 1977, pp 91-92.

${ }^{15}$ Lynda Garland, Matthew Dillon, Ancient Greece: Social and Historical Documents from Archaic Times to the Death of Socrates (c.800-399 BC). Taylor \& Francis, London, 2000, p 453.

${ }^{16}$ Xenophon, Scripta Minora. Constitution of Lacedaemonian ' s, (eng. transl. E.C. Marchant), William Heinemann Ltd., London, p 151.

${ }^{17}$ Herodotus, and A. D. Godley. Herodotus. Vol. IV, Cambridge, MA: Harvard University Press, 1969, pp 243-245.

${ }^{18}$ Joseph E. Fontenrose, The Delphic Oracle. Its Responses and Operations with a Catalogue of Responses, University of California, Berkeley, 1978, p 276.

${ }^{19}$ Violeta Šiljak, Olympism, Alfa University, Belgrade, 2013, p 8.
} 
it "20. This ancient boxer with his victories rose to the status of a mythological hero. Through the athletic agon, proving his arete, he ceased to be an ordinary mortal and became the embodiment of the highest male ideal in ancient society, deserving of divine glory and "the admiration of mortals". The case of Euthymus, however, is not an isolated example of such an experience of triumph among the Greeks. From Herodotus ${ }^{21}$ we learn that a temple was erected to a certain Philippus of Croton, in Egesta, where sacrifices were offered in his honour, and from Pausanias that there was a temple in Sparta dedicated to the wrestlers Hipposten and Etymocles, and that they were "in accordance with the prophecy", celebrated like the god Poseidon ${ }^{22}$. The most famous, however, is the example of the famous boxer, pankratian and runner, Theagenes of Thassos, who, in addition to his sanctuary on his native island, also had a centuries-old divine cult spread "all over the world", even among the non-Greek population ${ }^{23}$. On one occasion, exonerating his cult was even seen, by the Oracle of Delphi, as the only condition for saving the whole of Thassos from the troubles that befell it ${ }^{24}$. Common to all these athletes and heroes, was that they were Olympionics, winners, often multiple winners, in Olympia. Such stories were certainly an inspiration to young ambitious athletes in ancient times. Today, they are testimonies of great importance for understanding the enigmatic dedication and passionate zeal to win the competition for a seemingly ordinary wreath of wild olive branches.

The cult of the personification of the agon, in the form of an eponymous deity, was also found in Olympia itself. The Games, which were formed at that place traditionally in $776 \mathrm{BC}$, with the aim of bringing together the divided Greek tribes through religious ceremonies and ceremonies dedicated to the most important deity, in less than a century grew into events of immeasurable significance and popularity in the ancient world ${ }^{25}$, and have been writing their history for over twelve centuries. The Olympic Games, in ancient Greek O\YMПIAKOI AГONE $\Sigma$, in their very name, however, reveal a character significantly different from the

\footnotetext{
${ }^{20}$ Joachim Ebert, Griechische Epigramme auf Sieger an gymnischen und hippischen Agonen, Akademie Verlag, Berlin, 1972, pp 69-71.

${ }^{21}$ Herodotus, and A. D. Godley. Herodotus. Vol. IV, Cambridge, MA: Harvard University Press, 1969, p 51.

${ }^{22}$ A. R. Shilleto, trans. Description of Greece, Pausanias. London, George Bell, 1886., p. 195.

${ }^{23}$ Ibid. p. 381.

${ }^{24}$ Namely, the statue of Teagen fell and killed one of his enemies after his death, while the latter whipped him out of hatred for Teagen himself. According to the law of the time, the statue was convicted of murder and thrown into the sea. The Delphic prophecy, which announced the salvation of Thassos from drought if he returned all his exiles, included, among them, a statue of Teagen, which some fishermen later managed to pull from the bottom of the sea, after which his heroic cult was established (Ibid. pp. 380-382).

${ }^{25}$ Pindar, Odes and Fragments. Olympian I, (translated from Greek by: T. Smerdel), Matica Hrvatska, Zagreb, 1952, pp 39-44.
} 
context of casual, almost childlike innocent pastime, or even sports and recreational activities that the term "game" carries with it. Therefore, if we want to look at the ancient Ceremonial Games in Olympia in their true light, it is necessary to experience the Games as they were, relentless struggles, or competitions for honour ( $\left.\tau \mu \mu \eta^{\prime}\right)$, glory ( $\left.\kappa \lambda \dot{\varepsilon} o \varsigma\right)$ and the resulting public demonstration of excellence $\left(\alpha \rho \varepsilon \tau \eta^{\prime}\right)$ - the highest social ideal, with a large stake and sometimes too high a price of participation, and potential success.

Despite the fact that shifting the emphasis to athletic competitions, mostly equestrian, during the post-Mycenaean period paved the way for the participation of non-aristocratic athletes in athletic competitions, which was not the case until then $^{26}$, certain factors contributed to the selection according to which only the best among the few who met the requirements to approach the preparation at all could compete in Olympia. Competitiveness and demonstration of the arete was not only a part of the education of young aristocrats, but also of all Greeks. The demonstration of physical strength and fitness, through public competition and proving one's arete, completely coincided with the ideal of Greek masculinity with which most men of that time could identify. Based on later written sources, we learn that the number of participants in the Games was not proportional to the popularity and the number of interested candidates, so there were qualifying competitions that would precede the official ones. The selection of competitors, however, began months, even years before the given Games. When, during the third century BC. Sophist Philostratus in his work "On Gymnastics" described the reasons why Greece produces athletes far inferior to those of earlier times, the lack of systematic training and energetic motivation, are listed as the main ones ${ }^{27}$. This problem was certainly recognized centuries earlier, at least from the $6^{\text {th }}$ century BC. 28 29, which is the period when the first official sports facilities appeared in ancient Greece, with the purpose of sports education and systematic training, i.e. gymnasiums and palaestras. One of the oldest gymnasiums in Athens, with a mysterious name - Cynosarges, was accessible only to children of legitimate, full-fledged parents ${ }^{30}$, which is perhaps one of the indicators of its purpose in the context of Panhellenic competitions rather than general physical education ${ }^{31}$.

\footnotetext{
${ }^{26}$ Nikolaos Gialouris, Ancient Elis: Cradle of the Olympic Games, Adam editions, Athens, 1996, p 167.

27 Philostratus, Concerning Gymnastics, (eng. transl. Thomas Woody), Ann Arbor, 1936. Available at http://www.worldcat.org/title/philostratos-concerninggymnastics/oclc/17688376?referer=di\&ht=edition (accessed 26.05.2017).

28 Gordon Spencer Shrimpton, Theopompus the historian, McGill-Queen's University Press, Montreal, 1991, p. 239.

29 The oldest remains of a gymnasium with a palaestra were found in Delphi and date back to the 4 th century BC.

${ }^{30}$ The rules of participation in the Olympic Games in Olympia required that the competitor, as well as his parent, must take an oath not to violate the rules of the Games, as well as athletic preparation for at
} 
The significance of these facilities, apart from the immediate, training one, lies in the fact that it was in these facilities that the young Greeks met the selection for the first time, because every year, only those with satisfactory performance were selected to continue training. Thus, only athletes who excelled in gymnasiums and palaestras with their psychological and physical abilities, had the chance to participate in some of the local or Panhellenic Games. However, only the best among the chosen ones had the good fortune to go out to the stadium in Olympia ${ }^{32}$. Athletes had to achieve their first victories, which would later open the way for many of them to win the wreath at Olympia, in remote, anonymous gymnasiums and palaestras throughout Greece, without recognition, far from the eyes of the world. Only after showing a satisfactory level of training, but also competitiveness in the hometown, the athlete would set off for Olympia. There, after taking the oath in front of the statue of Zeus, about the dedicated training that lasted for ten months, and then confirming the free, full status of all competitors for men, i.e. the appropriate origin and age in competitions for boys, a one-month process of preparation would begin in Olympia under the supervision of Hellanodikai (judge). The goal of this training period was first to check the level of preparation and abilities of potential competitors, as well as to separate sufficiently competitive athletes from the weaker ones, regardless of their enthusiasm.

The Hellanodikai-s had their hands free to exclude inferior competitors, or create an atmosphere in which they would give up on their own. However, apart from Hellanodikai-s, the length of the period of one month, without any monetary compensation, was another measure against poorer athletes, or those who did not cultivate ambitions to win. Also, the distance of Elis from many Greek polises over extremely difficult terrain, undoubtedly discouraged mediocre athletes, without too much chance of winning in the first place. This high price, not only materially, of preparation and arrival to Olympia, was ready to be paid only by those who were ready to win, which is a position systematically supported by the organizers of the Games themselves. They tried to make every Game a spectacle, every discipline a counterpart to the modern derby, confronting the biggest competitors, while there was neither interest nor understanding for mere participation. On the contrary, the fear of shame caused by defeat was certainly not a negligible factor in an individual's decision to embark on an Olympic adventure. The judgement of

\footnotetext{
least ten months. (A. R. Shilleto, trans. Description of Greece, Pausanias. London, George Bell, 1886. p.352; Aleksandar Ćirić, Games in Olympia, Book time (Vreme knjige), Belgrade, 1996, p. 204.

${ }^{31}$ Plutarch , John Dryden, Arthur Hugh Clough, Plutarch's Lives, Little, Brown, and Co. Boston, 1875, p.231.

32 Theodoros Ioanidis, Đorđe Stefanović, Marija Karitou, Violeta Šiljak, Slađana Mijatović, The role and significance of gymnasium in preparing young people to compete in the Olympic Games in ancient Greece, Physical Culture, vol. 62 (1-2), 2008, p. 68.
} 
the athlete about his own arete could have been decisive in his further destiny, because the wrong one would bring shame and damage not only to him, but also to his family and his entire polis ${ }^{33}$. Thus, the athlete had to achieve minor personal victories before trying to achieve the most important one in Olympia, and gain the title of Olympionic.

\section{Victory in Olympia}

Pressed by long practices, the risk of being "strangled and cut in half" ${ }^{34}$, costs and strict selection criteria on the one hand and the proximity of the dream of an Olympic wreath coming true on the other, athletes left some of the most impressive feats in the history of sports at the Olympic Stadium. The immeasurable importance of the wreathing at Olympia, as well as the reasons why the athletes were willing to persevere on the thorny path to success, which they set out on their own, was best summed up by the Athenian orator Eshin, in the 4th century BC: "Do you think, fellow citizens, that any man, ever, would be willing to train pankration or some other of the more difficult disciplines at the Olympics ... if the wreath was bestowed not only to the best, but also to those who participated in the fight for it? No man would ever be willing to do such a thing. But because it is so, because rewards are rare ... and because of the competition, honour, and immortal glory that victory brings, people are willing to risk their bodies, and at the cost of the cruellest discipline survive the battle till the end" 35 . The uncompromisingness of the future winners, unmotivated to achieve any other result, except the grandiose success, is impressive.

In the few days of the Ceremonial Games, the athletes had a unique opportunity to prove their arete, so it was demonstrated in every possible form. Thus, fighters of more imposing build, or reputation, such as Milo of Croton or Theagenes of Thassos, demonstrated their obvious strength and physical superiority only by their appearance, and thus forced the opponent to give up rather than face serious injuries and humiliation. This case falls under a special type of victory - akoniti. Literally translated, the term means "dust-free" ${ }^{36}$, i.e. it means the case when the athlete does not need to be sprinkled with dust over his oiled body before the fight, because he has already won. This happened less often in cases when the athlete was the only one in the competition, or, more likely,

\footnotetext{
33 Pindar, Odes and Fragments, Pythian VI, pp 148-151.

34 A. M., Tr. Lucian. Harmon, Lucian. With an English Translation By A. M. Harmon. Vol. IV, William Heinemann; Loeb Library Edition edition, 1961, pp 9-11.

35 Aeschines and Adams, Charles Darwin, 1856-1938 The speeches of Aeschines. Harvard University Press ; London : W. Heinemann, Cambridge, Mass, 1961. p. 449.

36 The term was used only for martial arts in which dusting was used as preparation for combat, including wrestling as part of the pentathlon.
} 
when one of the competitors gave up due to a penalty ${ }^{37}$, out of fear or assessment that they had no chance against the favourite (which would explain the particular honour that the term carried with it). That the akoniti wore a halo of special prestige is also shown by the tone in which the dedication of the pentathlete Acmatida was written, where the separation of the akoniti from the usual way of victory is certainly worthy of attention. In $500 \mathrm{BC}$, he dedicated a stone halter on Altis $^{38}$ after winning the pentathlon. On the halter, preserved in the museum in

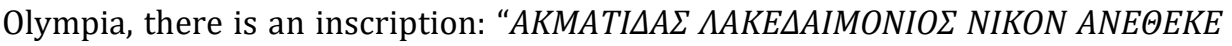
TA ПENTE A $\Sigma K O N I K T E I$ ", i.e.: "Acmatida the Lacedaemonian (Spartan) dedicates (this) by winning five (in pentathlon) dust-free (akoniti)"

The second story, related to akoniti but also to the unbridled hunger for competition and victory, once again brings to the fore Theagenes of Thassos. At the 480 BC Games, which took place despite the bloody battles during the Persian invasion, Theagenes, overestimating his abilities, entered both the competition in pankration and boxing. However, after a difficult match against another legendary fighter, the aforementioned Euthymus from Locri, exhausted Theagenes gave up on pankration, so his opponent Dromeus of Mantineia took the victory akoniti. Theagenes, however, did not earn any sympathy because of his ambition, but, since it was estimated that he applied for the boxing competition only because of rivalry and personal animosity towards Euthymus, he was punished with two talents for this greed ${ }^{39}$. One he would have to pay to the temple of Zeus, and the other to Euthymus himself ${ }^{40}$.

The result, probably an increase in corruption and bribery of both judges and rivals in competitions during the Hellenistic era (c. 323-30 BC), were threatening bronze statues of Zeus, built in the early 4th century BC, on a stone platform at the foot of Cronion Hill near the Stadium, from fines paid by those who desecrated the competition by committing frauds. An inscription from one of them warned that "... the Olympic victory is not achieved with money, but with the speed of the legs

\footnotetext{
37 The term was used only for martial arts in which dusting was used as preparation for combat, including wrestling as part of the pentathlon.

${ }^{38}$ Halters were mostly made of stone, less often metal, weights that during the alma, long jump, the jumpers held in their hands until before the landing, in order to increase the length of the jump and stability during the landing (Šiljak, 2007, p. 52), which "gave wings" (Philostratus, Concerning Gymnastics, p. 55). Ancient sources tell us about two types of these weights, round and elongated, weighing between $1.5-2.5 \mathrm{~kg}$, with the exception of Akmatid's halters of 4,629 kg. Halters were most likely the personal property of the athlete, made according to his needs, and are a common item that pentathletes dedicated to Olympia.

39 Talent, quantity of $26 \mathrm{~kg}$ of silver or its nominal value. 1 talent $=6000 \mathrm{drachmas}$. It is difficult to estimate the exact value of the drachma in this period, but, for comparison, one drachma was a per diem for a good worker or hoplite (soldier) a few decades later (Thucydides; R. B. Strassler; R. Crawley, The landmark Thucydides: a comprehensive guide to the Pelopennesian War, New York: Free Press, 1996, pp. 166-167).

${ }^{40}$ A. R. Shilleto, trans. Description of Greece, Pausanias. Vol. 1, London, George Bell, 1886, pp 371-373.
} 
and the strength of the body", while the inscription below one of the statues ominously stated that it stands there "..,because of the respect for the gods by the Elisians, and because of the warning to athletes who would try to break the law" 41. The making and erection of one of the six statues, according to Pausanias ${ }^{42}$, is the epilogue of an incident caused by a certain Calypso from Athens in 332 BC, one in a series of bribery incidents ${ }^{43}$. Victories, "at any cost", at least according to sources, seem to have been particularly prone by rivals from the Greek colonies of present-day southern Italy, eager for their place in the pantheon of victors and glory in competition against their eastern compatriots, so they often did not refrain from trying to bribe the winners or political bravado in the context of naturalizing athletes ${ }^{44}$.

That nothing could stop the ambition of the athlete in the quest for eternal glory is also shown by the example of the Spartan Likai, the owner of the fourwheeler crew. Despite the ban that all competitors from Sparta had in 420 BC due to the punishment prescribed to them by the Elisian organizers, he brought his equestrian team to compete under the "flag" of Thebes, believing that he could win the wreath. However, when, after the victory, his identity was revealed, old Likai was humiliated and whipped, and his name was deleted from the list of winners. Moreover, the Spartans were completely forbidden access to the sanctuary. As expected, they responded with a military intervention on Elis, with which they were already in extremely bad relations at the time, and destroyed it with "axe and fire", demonstrating their superiority ${ }^{45}$. It was obviously extremely dangerous to take away the wreath and glory from the winner. However, apart from minor violations of the rules ${ }^{46}$ in the disciplines themselves, a relatively small number of sources dealing with fraud and scandal, especially during the earlier, more glorious period of the Games, testify to the general (fearful) respect for the rules and integrity of the Games and fair competition in Olympia. The wellknown history of the Ceremonial Games in Olympia remembers data on 794 named winners, or 1094 recorded victories. Among them are some of the

\footnotetext{
41 Ibid., p 343.

42 Ibid., p 344.

43 Pausanias describes several other cases of bribery on the part of wrestlers, poets, and even the parents of competitors. He also cites cases of violation of "fair play" by the helanodics themselves (Ibid., pp. 345-366).

44 Ibid., p 396; Clarence Forbes, Crime and Punishment in Greek Athletics, The Classical Journal, Vol. 47, No. 5, 1985, p 169, available at: http://www.jstor.org/stable/i365839 (accessed on April 22, 2014).

${ }^{45}$ Xenophon / with an Engl. transl. by Carleton L. Brownson, London : Heinemann [u.a.], 1961, p 211.

46 Themistocles, in the famous story of Herodotus, is more ready to be whipped for breaking the rules in the form of an earlier start in the race, than to be left without a wreath due to a late start. (Herodotus, and A. D. Godley. Herodotus. Vol. IV, Cambridge, MA: Harvard University Press, 1969, p. $55)$.
} 
impressive examples of early athletics, deserving of admiration even after more than two millennia.

However, there was also a hierarchy of success among the Olympionics. Thus, the triastes was the title for the winner among the winners, the one who managed to win in three disciplines in one game. Only a few managed to achieve that, and, interestingly, all in the same disciplines. The first record of the triastes comes from $512 \mathrm{BC}$ when victories in the stadion, diaulos and hoplitodromos were achieved by the runner Phanas of Pellene. Infamous Astylos of Croton, at the Games in 480 BC when he played for Syracuse, became a triastes in the same disciplines. Their footsteps, almost five centuries later, were followed by Nicocles of Arion (100 BC), Hecatomon of Miletus (72 BC), Polit of Keramna (69 BC), Hermogenes of Xanthus (81 and $89 \mathrm{BC}$ ). However, no one succeeded in what Leonidas of Rhodes managed to achieve. Between 164 and $152 \mathrm{BC}$, Leonidas managed to do the impossible. He won as many as four consecutive times in three disciplines - stadion, diaulos and hoplitodromos. With twelve wreaths, he is by far the most successful athlete among Olympic winners.

From ancient writers we learn the names of those older, and perhaps more famous winners. From Pausanias ${ }^{47}$, we learn that Chionis of Sparta, one of the best runners in Olympia, won as many as seven wreaths there, and that on the plaque that Pausanias had the opportunity to see numerous victories in other competitions were inscribed as well. It is also interesting for Chionis to hold the record in the long jump ${ }^{48}$, a record of fantastic $16.66 \mathrm{~m}^{49}$, which he achieved by competing in the pentathlon, in which he never won. His fellow citizens won the most wreaths in Olympia, especially in the earlier period of the Games, when the wrestling scene was literally ruled by the aforementioned father and son, Hipposten and Etymocles, who were undisputed wrestlers with six or five consecutive victories for more than four decades. According to the number of victories with the Spartan athletes, only the Crotons could measure up. The most famous among them is certainly the legendary Milo. His popularity grew so much in the years after his death that the stories that circulated about his life and death moved into the realm of the mythological. The myth of Milo was created exclusively thanks to his victories in Olympia, five consecutive ones, from 532-516 $\mathrm{BC}$, including a victory in the competition for the boys. Of Milo's compatriots, a large number of them stood out in the Stadium, so Hippostratus, Isomachus, Tisicrates and the mentioned Astylos won two wreaths only in Olympia. Gorg of

\footnotetext{
${ }^{47}$ A. R. Shilleto, trans. Description of Greece, Pausanias. Vol. 1, London, George Bell, 1886, p 196.

${ }^{48}$ Frank Zarnowski, The pentathlon of the ancient world, McFarland, Jefferson USA, 2013, p. 61.

${ }^{49}$ Due to this exceptional result, it is generally considered that the jump with halters was actually a triple jump.
} 
Elis, who is not among Hippia's winners, is mentioned by Pausanias ${ }^{50}$ as a famous winner who achieved triumph four times in pentathlon and once in diaulos and hoplitodromos. Among the Olympic winners, there were also prestigious so-called periodonike, winners of all four major competitions held in Greece during a fouryear competition cycle. Among those who had the honour to carry this prestigious title are the mentioned Theagenes of Thassos, Diagoras of Rhodes, the founding father of so-called Diagorides, the line of winners in Olympia, Melankomas of Caria, Polydamas of Skotoussa, Milo of Croton and others. ${ }^{51}$

Still, perhaps the most deserving of today's interest and effort to understand the ideological significance of the urge to compete, as the only Greek phenomenon that has not appeared in such form anywhere else, are the athletes who chose death before the defeat on the athletic field. Pausanias ${ }^{52}$ reports that during his visit to Figaleia, he came across a very old statue of the archaic type, already eroded by the ravages of time with the inscription erased at the foot. Namely, the statue was dedicated to a certain Arrachion of Figaleia, who, until the 54th Games in $564 \mathrm{BC}$, had won two wreaths in pankreation. At that game, in $564 \mathrm{BC}$, during the final fight, Arrachion found himself in an unenviable situation while wrestling in the partierre position (as part of a pankration). The opponent overtook him, attacked first and scissored him with both legs, suffocating him with his arms wrapped around his neck. In agony, Arrachion refused to raise a finger in surrender. Losing consciousness, with the last atoms of strength, he dislocated the toe of his opponent, who was forced to surrender the fight due to terrible pain. Arrachion, however, exhaled his last breath in the meantime, being suffocated to death. After he surrendered the fight, the opponent of Figaleian could not be wreathed as the winner, and the judges decided to award the victory to the dead Arrachion. Thus, he was wreathed in pankration for the third time, becoming one of the most successful pankratists in the history of the Games ${ }^{53}$. The case of Arrichion is even more dramatic if we accept the conclusion of R. Brophy ${ }^{54}$, according to whom his death was actually caused not by the intervention of the opponent, because in such interventions unconsciousness occurs significantly before death, by which time the fight would have been stopped, but by Arrichion's

\footnotetext{
${ }^{50}$ A. R. Shilleto, trans. Description of Greece, Pausanias. Vol. 1, London, George Bell, 1886, p 390.

51 Ćirić, Games in Olympia, p. 213.

${ }^{52}$ A. R. Shilleto, trans. Description of Greece, Pausanias. Vol. 2, London, George Bell, 1886, p 127.

${ }^{53}$ Apart from Arachion, only Dorie from Rhodes, Sostrat from Sikyon and, a little later, Astyanax from Miletus had three victories in Olympia.

54 Robert Brophy \& Mary Brophy. Deaths in the Pan-Hellenic Games: Arrachion and Creugas, The American Journal of Philology, Vol. 99 (3), 1978, pp. 363-390, available at http://www.jstor.org/action/showShelf? candidate=10.2307/ 293747 (accessed 17.06.2014).
} 
desperate twitch, causing a fatal neck injury, in an attempt to defeat the opponent and win.

\section{THE SIGNIFICANCE OF AN OLYMPIC VICTORY}

Successfully completed competition in battle, on an athletic arena or other feats, for a mythological hero like Hercules, one of the greatest and most influential figures of the ancient times, were a means of proving one's honour, affirming reputation, political or military legitimacy, and generally demonstrating superiority. This instrument is, moreover, common to all the great mythological heroes of Greece: Theseus, Perseus, Castor and Polydeuces, Achilles, Odysseus, Hercules, Pelops, etc. A heroic cult like the one of Heracles, which inspired athletes to undress ${ }^{55}$ and surpass all opponents in agon, imitating feats and victories but also his immortality as a hero, was based on fantastic athletic abilities, which were part of his heroic identity, inseparable from other aspects of his life. Winners in all life's challenges, heroes, set an example of excellence, especially athletic one. Equating or at least approaching such an ideal, could not have been a mere incidental motive. However, the adoption of the ideology of the heroic cult among athletes reaches its full and clear form just at the time when egalitarian aspirations give birth to the polis.

The question arises whether and how the two worlds - the world of individual, mostly aristocratic arete of heroic victors, and the general sense of belonging to the community, i.e. the polis, reconciled? What prompted polises to demonstrate pride and interest in the obviously individual feats of its citizens through their activities? Observing the agonistic competition as the last stronghold of the individualistic, heroic ethics of the Greek aristocracy, one can clearly see the conflict with the general trend of emphasizing the community of newly formed polises. The opportunity to immortalize their victories with epinician odes and statues was an essential element of their self-promotion. It cannot be said with certainty when the first epinicion that brought divinity to athletic competition dates, thus creating a connection between two worlds or, as Pindar himself said 56 “... between mortals who are worthless and gods who live forever ... ". The first surviving victory ode is the work of Simonides of Ceos, but the ancient tradition often attributes the introduction of this custom to Archilochus. In any case, it is

\footnotetext{
55 For most of its history, ancient athletic disciplines have been known as ГҮMNIKOI AГ $\Omega N E \Sigma$, naked competitions, because of the way athletes competed.

56 Pindar, Odes and Fragments. Nemean VI, (translated from Greek by: T. Smerdel), Matica Hrvatska, Zagreb, 1952, pp 204-207-
} 
certain that the victory odes in one form or another have existed since the very beginnings of athletic competition ${ }^{57}$.

Epinician odes are odes to the individual, the winner, which emphasize his athletic arete, as well as the glory of his lineage, family or the dynasty to which he belongs, which is one of the most important elements of the aristocratic arete. However, as such an insistence on the individual can upset the balance between the individual and the polis, the aristocratic winners, that is, the poets who composed the odes, managed to find a way to reconcile the two extremes. The odes thus took the form in which they were presented as public goods, they were announced in the name of the winner, from which the whole community of polis would benefit. Therefore, athletes who, to some extent, certainly had to feel distant and excluded in their almost fanatical commitment to the goal, no longer appeared in their dedications of victory as sons of their fathers ${ }^{58}$ but as members of their polis. Thus, Acmatida is recognized only as a Lacedaemonian, Milo as a Croton, and Theagenes as that of Thassos and the like. And while in the "outside world" the identification of individuals according to the polis was usually the case with those of unknown origin, among athletes it was an unwritten rule. Epinician odes went a step further, so the polis was openly celebrated, its tradition and history mentioned, and the winner himself called the "son of the polis" 59.

Thus, the gap between the elitist ethos and self-promotion, and the interests of the general community in the polis, narrowed. The Epinician odes found a way to painlessly reintegrate the athlete into a society that abandoned aristocratic ideals, but which managed to accept his personal victory and fame as a joint one, as part of the general cultural heritage of the polis and its promotion. In addition, the athletes themselves, while raising the winning statues as part of their victory, selflessly turned to society, expressing their moral arete through nobility, generosity and patronage potential. Thus, part of the individual's celebrations became public feasts or events organized by the Olympionic himself, in this case. Expressing a desire for their own arete through the form of the public good of the polis, the athletes continued their march towards their heroic status, approved and accepted by the wider community of the polis.

However, what, in fact, was the interest of the polis in all this? Many polises provided prizes to their citizens, winners of the Panhellenic Games, such as money, honorary seats at festivals, exemptions from paying taxes, the

\footnotetext{
57 Anne Pippin-Burnett, The art of Bacchylides. Cambridge, Mass: Published for Oberlin College by Harvard University Press, 1985, p. 38.

58 Adding the father's name after his name, more closely identified the individual, that is, his origin. Today, that custom has been largely replaced by a surname, but the so-called middle name, still held.

${ }^{59}$ Pindar, Odes and Fragments. Olympian II, (translated from Greek by: T. Smerdel), Matica Hrvatska, Zagreb, 1952, pp 45-52.
} 
aforementioned part of the status of royal bodyguards, free meals at the prytaneion, and even status of citizen. From the beginning of its history, Olympia was an ideal location for the public promotion of the aristocracy's own glory, but it was also an extremely fertile ground for expressing the aspirations of the polis, whether political - in the case of strong polises with hegemonic ambitions, or commercial - through promoting artistic and craftsmanship skills in the ancient equivalent of marketing, in the case of the weak polises ${ }^{60}$. Relatively early on, the polis realized that they could gain fame extremely effectively at the expense of personal victory and the honour of some of its fellow citizens. They soon made sure that the athletes, especially at the four Stephanitic games, became representatives of their polises, behind which the whole community would stand, provide support and which would compete for their fame that would later, in mutual interest, be appropriated by the whole polis.

Thus, the appearance of dedications and treasures in Olympia during the archaic period, behind which the sponsors were the polises, and not exclusively individuals, testifies to the coming together of two worlds and two ideologies. The sanctuary is no longer exclusively an aristocratic playground, but the polis has also found its interest there. Polis acknowledges, even celebrates the individual feat of his fellow citizen, because it allows him to claim the right to his honour, glory, and primarily the favour of the gods, necessary in the global, political agon, in which, as already mentioned, he himself was included. By building treasuries, as well as erecting monuments to the military or some other victory in the sanctuary of Olympic significance, the polises were included in direct competition with other polises $^{61}$. In those battles, the athletes, more precisely their victories at the Games, were an extremely valuable trump card. As celebrated individuals, the winners of athletic competitions were thus the embodiment of the ideals of the aristocratic elite in search of heroic immortality, while working in the interest of the wider community of the home polis, which eagerly awaited identification with its newly acquired honour and reputation. In return, the polises often did not spare the money invested in training and sending the athlete to the Games, and especially did not spare on celebrating his victory. The power of victory and its ability to defend and legitimize political power remained well preserved in both aristocratic and democratic societies in Greece, which, each in their own way, profited at the expense of the enormous power of the prestigious kleos the victor.

\footnotetext{
60 Catherine Morgan, Athletes and oracles. The transformation of Olympia and Delphi in the eighth century BC. Cambridge University Press, Cambridge England, 1990, pp 2-3.

61 Panos Valavanes, Games and sanctuaries in ancient Greece. Olympia, Delphi, Isthmia, Nemea, Athens. J. Paul Getty Museum. Los Angeles, 2004, available at:

http://books.google.rs/books?id=njwKAQAAMAAJ\&hl=sr, (accessed on March 13, 2014), p 228.
} 


\section{CONCLUSION}

The results of the research indicate that the urge to compete was the main driving force for the development of ancient Greek culture, on the basis of which, thanks to its constant search and need for excellence, the philosophy of Western civilization rests today. Permeating all aspects of the life of the ancient Greeks, agon arose as a consequence of innate rivalry among people (the good, morally pure, which encourages perfection and progress), controlling the minds of slaves, children, women, artists, warriors, athletes and rulers, even polises themselves. On the basis of agon, the most deserving ones, the best ones, representatives of their craft, their place, their polis were elected, and based on that, a hierarchy was established in Greek society, ranging from hierarchy among sculptors in the workshops, through hierarchy in the ruling class, to hierarchy among polises on the entire Panhellenic scene.

Thus, agon, as the main driving force of Greek society, was responsible for the formation of one of the oldest and longest-lasting institutions - the Olympics Games. The Games themselves were the place of the embodiment of agon in its purest form, the arena of proving individual excellence, the search for the heroic ideal, approaching the gods and establishing supremacy. Numerous monuments remain to testify to the tireless search for immortality, the cult of triumph and the imperishable glory of the Olympic victory. Agon survived the various epochs of ancient Greece and the changes that brought with it, and survived as a means of achieving immortality, which will lead all future athletes to demonstrate fantastic abilities in an attempt to achieve it. This research sheds light on doubts about the significance of winning the Olympics and points out errors in their interpretation and identification with the modern Olympic Games. It was not important to participate in the Ceremonial Games in Olympia, it was important to win.

\section{REFERENCES}

1. A. M. Tr. Lucian. Harmon, Lucian. With an English Translation By A. M. Harmon. Vol. IV, William Heinemann; Loeb Library Edition edition, 1961.

2. A. R. Shilleto, trans. Description of Greece, Pausanias. Vol 1., London, George Bell, 1886.

3. Aeschines and Ada

4. ms, Charles Darwin, 1856-1938 The speeches of Aeschines. Harvard University Press ; London : W. Heinemann, Cambridge, Mass, 1961.

5. Aleksandar Ćirić, Games in Olympia [Igre u Olimpiji], Book Time [Vreme knjige], Belgrade, 1996.

6. Anne Pippin-Burnett, The art of Bacchylides. Cambridge, Mass: Published for Oberlin College by Harvard University Press, 1985.

7. Catherine Morgan, Athletes and oracles. The transformation of Olympia and Delphi in the eighth century BC. Cambridge University Press, Cambridge England, 1990. 
8. Clarence Forbes, Crime and Punishment in Greek Athletics, The Classical Journal, Vol. 47, No. 5, 1985, available at http://www.jstor.org/stable/i365839 (accessed 22.04.2014).

9. David Young, „On the Source of the Olympic Credo“, OLYMPIKA, The International Journal of Olympic Studies, Vol. III, 1994.

10. Đorđe Stefanović, Theory and practice of sports training, Faculty of Sports and Physical Education, Belgrade, 2006.

11. Frank Zarnowski, The pentathlon of the ancient world, McFarland, Jefferson USA, 2013.

12. Gordon Spencer Shrimpton, Theopompus the historian, McGill-Queen's University Press, Montreal, 1991.

13. Herodotus, and A. D. Godley. Herodotus. Vol. 3, Cambridge, MA: Harvard University Press, 1969.

14. Hesiod, Works and Days. The origin of the gods. Homer's Hymns, (translation Branimir Glavičić), Demetra Filological Library Dimitrija Savića, Vol 6, Zagreb, 2005.

15. Homer, Iliad, (translation. M. N. Đurić), Matica Srpska, Subotica, 1977.

16. Homer, Odysseys, (translation. M. N. Đurić), Matica Srpska, Subotica, 1977.

17. Joachim Ebert, Griechische Epigramme auf Sieger an gymnischen und hippischen Agonen, Akademie Verlag, Berlin, 1972.

18. Joseph E. Fontenrose, The Delphic Oracle. Its Responses and Operations with a Catalogue of Responses, University of California, Berkeley, 1978.

19. Lynda Garland, Matthew Dillon, Ancient Greece: Social and Historical Documents from Archaic Times to the Death of Socrates (c.800-399 BC). Taylor \& Francis, London, 2000.

20. Nikolaos Gialouris, Ancient Elis: Cradle of the Olympic Games, Adam editions, Athens, 1996.

21. Panos Valavanes, Games and sanctuaries in ancient Greece. Olympia, Delphi, Isthmia, Nemea, Athens. J. Paul Getty Museum. Los Angeles, 2004, available at http:// books.google.rs/books?id=njwKAQAAMAAJ\&hl=sr, (accessed 13.03.2014).

22. Philostratus, Concerning Gymnastics, (eng. transl. Thomas Woody), Ann Arbor, 1936. available at http://www.worldcat.org/title/philostratos-concerninggymnastics/oclc/ 17688376? referer=di\&ht=edition (accessed 26.05.2017).

23. Pindar, Odes and fragments, (translation from Greek by T. Smerdel), Matica Hrvatska, Zagreb, 1952.

24. Plutarch, John Dryden, Arthur Hugh Clough, Plutarch's Lives, Little, Brown, and Co. Boston, 1875.

25. Robert Brophy \& Mary Brophy. Deaths in the Pan-Hellenic Games: Arrachion and Creugas, The American Journal of Philology, Vol. 99 (3), 1978. available at http:// www.jstor.org/action/showShelf?candidate $=10.2307 / 293747$ (accessed 17.06.2014).

26. Theodoros Ioanidis, Đorđe Stefanović, Marija Karitou, Violeta Šiljak, Slađana Mijatović, The role and significance of gymnasium in preparing young people to compete in the Olympic Games in ancient Greece, Physical Culture, vol. 62(1-2), 2008.

27. Thucydides.; R. B. Strassler; R. Crawley, The landmark Thucydides: $a$ comprehensive guide to the Pelopennesian War, New York: Free Press, 1996. 
28. Violeta Šiljak, History of Sports, Faculty of Sports Management, Belgrade, 2007.

29. Violeta Šiljak, Olympism, Alfa University, Belgrade, 2013.

30. Violeta Šiljak, Slađana Mijatović and Ivana Parčina, Politics and the Olympics, Topics [Teme], vol. 37, no. 2, 2013.

31. Xenophon / with an Engl. transl. by Carleton L. Brownson, London: Heinemann [u.a.], 1961.

32. Xenophon, Scripta Minora. Constitution of Lacedaemonian's, (eng. transl. E.C. Marchant), William Heinemann Ltd., London.

\section{АГОН И ЗНАЧАЈ ПОБЕДЕ НА СВЕЧАНИМ ИГРАМА У ОЛИМПИЈИ}

\section{САЖЕТАК}

Идеологија једног од најзначајнијих глобалних спортских догађаја данашњице, модерних Олимпијских игара, окренута учешћу пре него победи, промовисању једнакости учесника пре него доминацији победника над побеђенима, установила је идеалне моделе спортског понашања и спортске етике данашњице сматрајући да их темељи на вредностима античког друштва. Предмет овог рада се односи на агон и значај победе на Свечаним играма у Олимпији. Циљ рада је да се кроз преиспитивање примарних и секундарних историјских извора утврди значај победе на Свечаним играма у Олимпији и да се укаже на повезаност победе са агоном. Резултати истраживања указују на чињеницу да су Свечане игре у Олимпији биле обликоване општегрчким феноменом изражене компетитивности или агона, концепта часног ривалитета у свим сферама друштвеног живота, са сврхом доказивања изврсности и надмоћи над конкурентима, а који је као такав постао главна покретачка сила развоја античке Грчке културе, на чијим основама данас почива читава западна цивилизација.

Кључне речи: нагон за надметањем, античка Грчка, Олимпијске игре, победа

\section{СОСТ ЯЗАНИЕ И ЗНАЧЕНИЕ ПОБЕДЫ НА ЦЕРЕМОНИАЛЬНЫХ ИГРАХ В ОЛИМПИИ}

\footnotetext{
АННОТАЦИЯ

Идеология одного из важнейших мировых спортивных событий сегодняшнего дня, современных Олимпийских игр, ориентированная на участие, а не на победу, пропагандирующая равенство участников, а не доминирование победителей над побежденными, установила идеальные модели спортивного мастерства и спортивной этики сегодняшнего дня,
} 
основанные на ценностях древнего общества. Проблема статьи касается состязания и значения победы на Церемониальных играх в Олимпии. Цель статьи состоит в том, чтобы определить значение победы на Церемониальных играх в Олимпии посредством обзора первичных и вторичных исторических источников, а также указать на связь между победой и состязанием. В статье применяются как исторический метод, так и метод теоретического анализа. Результаты исследования указывают на то, что Церемониальные Игры в Олимпии были сформированы общегреческим феноменом выраженной конкуренции или состязания, концепцией честного соперничества во всех сферах общественной жизни с целью продемонстрировать отличные спортивные качества и превосходство над конкурентами, и которые стали главной движущей силой развития древнегреческой культуры, на фундаменте которой сегодня основывается вся западная цивилизация.

Ключевые слова: стремление к соревнованиям, древняя Греция, Олимпийские игры, победа 